\title{
THE ZONES OF TURBULENCE IN THE RUSSIAN AUDIT MARKET
}

\author{
Karagod V.S. ${ }^{1}$, Golubeva N.A. ${ }^{2}$, Erokhina E.I. ${ }^{3}$ \\ ${ }^{1}$ Doctor of Economic Sciences, Professor, The National Research Nuclear University "MEPhl", \\ Russia, v.karagod@yandex.ru \\ ${ }^{2}$ Candidate of Economic Sciences, Docent, Peoples' Friendship University of Russia, Russia, \\ golubevana@pfur.ru \\ ${ }^{3}$ Postgraduate, Peoples' Friendship University of Russia, Russia, erokhinaei@mail.ru
}

\begin{abstract}
The situation that arose on the Russian auditing market became the subject of analysis of this publication. Long-term monitoring of the processes of audit services that arose on the Russian market allowed the authors to determine and critically comprehend the cause-effect relationships of the existing crisis phenomena and errors in the regulation of audit activities.

The purpose of the research was to identify the features and patterns development of the Russian audit market, clarifying and systematizing the main crisis zones of regulatory legal regulation of audit activities in Russia.

Results: The authors presented detailed analysis of the development and the state of the Russian audit market, the main factors under which it developed and its main problems.
\end{abstract}

Keywords: auditor activity, the market of auditor services.

\section{INTRODUCTION}

The Russian audit market initially has its own specific endemic features. The institute of Russian audit emerged at the behest of the Government, but in the third decade of its existence it survives in the conditions of constant changes in the regulatory framework, various legislative initiatives and social experiments. As a result, the systemic errors of the regulator led to an avalanche of problems that pose a threat to the very existence of Russian audit in the approaches to the audit institution recognized by the international community. Professionals [4], [10], [16] and scientifics [8], [9], [11], [17] general public consistently attracted the attention of the regulator to internal problems of the audit egregor and potential risks of agency relations of the audit services market. But, in the opinion of the head of the auditing company "FBK Povolzhye", Nikiforov S.L. said that- "The Ministry of Finance of the Russian Federation, no crisis, and there were no special problems on it" [5, by Tsit. on, p. 10]. Evgeny Samoilov, partner of "Baker Tilly Russia", is more categorical: "Audit does not represent any value for the state, it does not need it. No one in the state is 
interested in ensuring that the companies that own it have reliable accounts. There are no penalties, no responsibility for providing unreliable accounts. "[10, by Tsit. on]. "Audit is not an additional financial burden, but the need for business development", says Igor Zhuravlev, a member of the Management Board of NP "Opora Rossii". If entrepreneurship in Russia goes on the path of survival, then it must be freed from audit and preferably at the same time from taxes, if development is necessary". [1, by Tsit. on].

The state of discomfort is the main enduring feeling of all participants of the audit market, which does not disappear even on the eve of the upcoming reforms initiated by the President of the Russian Federation, Putin V.V., and not the auditing regulator - the Ministry of Finance of Russia. In his Order of the 19th of December, 2015 to the Chairman of the Government of Russia, Medvedev D.A., the President identified the main directions of necessary changes:

- the increasing the role of the institution of audit and the level of demand for its results;

- the determination of priority directions for further development of audit activities in the country (in Russia);

- the formation of conditions ensuring the competitiveness of domestic auditors, including in the international markets for audit services;

- to increase of effectiveness and quality of mandatory audit.

These areas should ensure the modernization of the domestic audit model in the vector of compliance with the objectives of public policy. The Concept of further development of audit activity in the Russian Federation with the implementation plan for the period 2018-2019 year [14] and guaranteeing an effective model of auditing regulation in the opinion of the Government, in fact, has an element of novelty only in the appointment of the regulator of the auditing activities of the Central Bank of the Russian Federation (hereinafter - Central Bank of Russia). The main array of areas of development and goals has not been changed. Based on the logic of continuity, the subject of our research will be the diagnosis of crisis symptoms of the Russian audit market.

\section{SOURCES AND METHODS}

The research is based on the methodology of the historical-comparative approach, in the context of which the problem-chronological and historical-genetic methods are applied. As part of checking the results of observations with a historical and logical approach to studying the sentiments of market participants in audit services, a survey was conducted of representatives of 25 audit firms (hereinafter - AF) on the main risks of the audit market 2016.

The information base of the research was served as data published in free access: information from the Ministry of Finance of Russia; sites of professional public organizations and data of market monitoring rating agencies and the mass media.

\section{RESULTS}

The retrospective degree of concentration of the Russian auditing market from 2000 year and the present time, allows us to state that with the constant density of the number of AF in the Central and North-Western regions, in 2000-2008 year a greater number of audit organizations were located on the periphery from the centre. From the point of view of market processes, the years 2000-2008 coincide with two waves of optimism [4], when the prospects for the development of audit in the society were idealized, which was reinforced by the understated parameters of determining the mandatory nature of the audit. After 2008 year, the situation begins to change due to the introduction of second-generation standards, a reduction in the number of organizations subject to compulsory audit, stagnation of the economy due to the global economic crisis, etc. Currently, the audit market is concentrated in the centre of the country in two major cities Moscow (the capital) and St. Petersburg, with selected active regions: the Urals, Siberia, the Far East and the Crimea. There are 3 positions for visualizing this output in the Fig.1. 


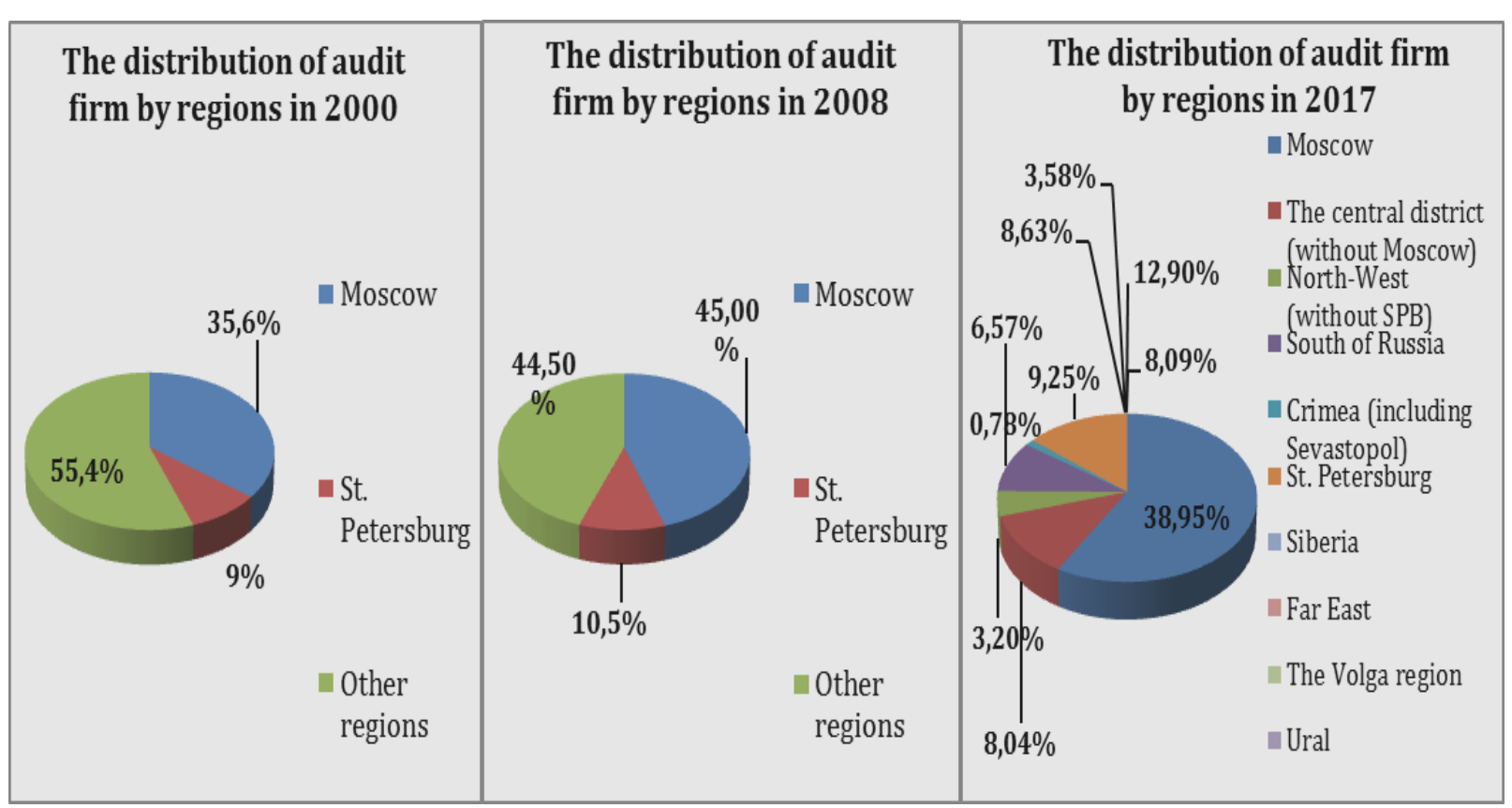

Fig.1.The distribution of audit firms by regions of the Russian Federation Source: compiled by the authors based on [15]

Th changes that took place after the adoption of the second Law "On Auditing" in 2008 year (hereinafter $307-\mathrm{FZ}$ ) sharply reduced the guaranteed volume of compulsory audit, which led to a reduction in the number of AF (Fig. 2) and the emergence of a characteristic feature of the Russian audit - dumping prices.

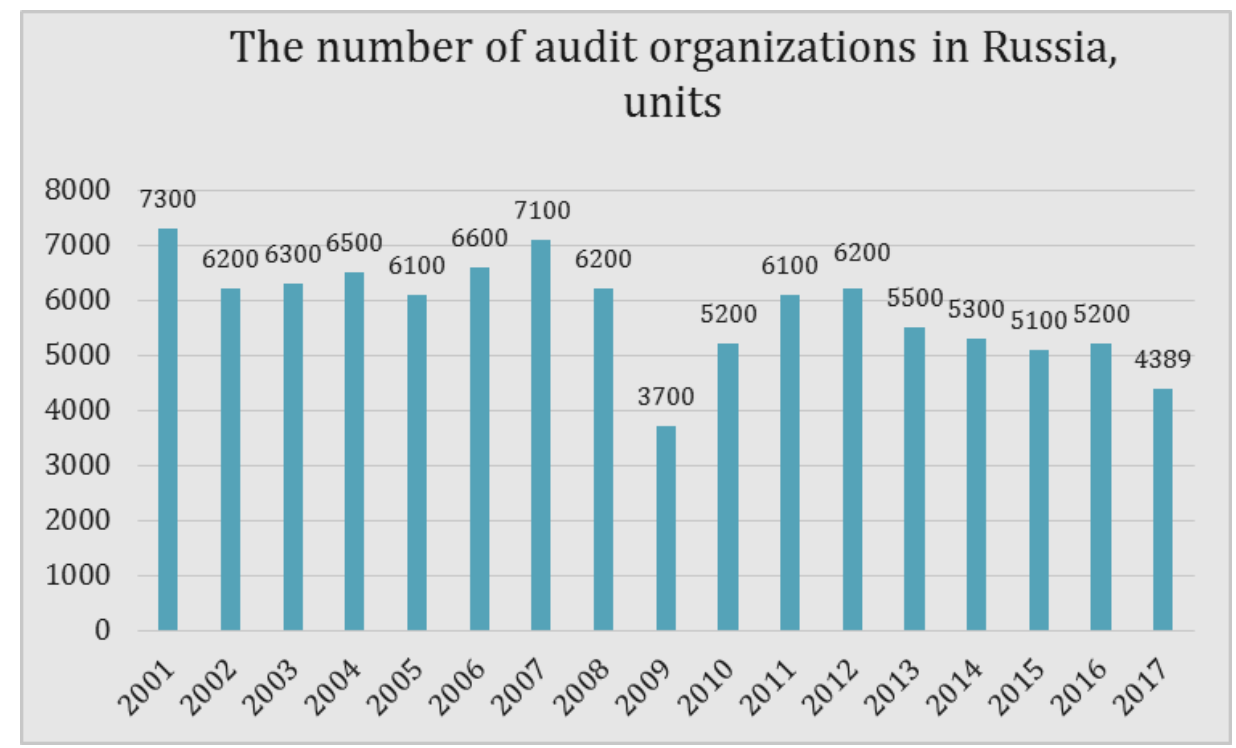

Fig.2. The number of audit organizations in Russia, units Source: compiled by the authors based on [15]

\subsection{The Problem of Mandatory Audit:}

The prevailing view is that the increase in the criteria for compulsory auditing in 2010 year in terms of revenue from 50 to 400 million rubbles, and balance assets from 20 to 60 million rubbles - the starting point of the audit crisis in Russia, remains controversial for the last three years.

The Director of the Accounting, Financial Reporting and Auditing Department of the Ministry of Finance of Russia, Schneidman L.Z. in 2013 year, on this occasion, clearly expressed: - "For many years the market was held mainly on the fact that the state imposed compulsory audit on entrepreneurs. And part of the auditors frankly parasitized on this. Because it was not necessary to strain hard, think about the image, reputation, quality of the services provided". [3, by Tsit. on]. In our opinion, we should not be so categorical, since compulsory auditing is more expensive, both in terms of mandatory procedures and the use of 
intellectual potential (hereinafter - IQ - potential) than any other audit services.

It is noteworthy that Nikiforov A.S. [5, from p. 11], the Director of one of the major AF, in a softer form, but also believed that the obligation of auditing is dictated only by the public need, and also gave examples of mandatory audits of municipal kindergartens and laundries. In the June 2017 was meeting Nikiforov A.S. with representatives of the Central Bank of Russia to discuss new regulatory and legal approaches to regulating audit activities. On this meeting he expressed concern that in the region where his AF operates, "when implementing the proposals of the Central Bank of the Russian Federation, the number of audited companies will be reduced by $99 \%$. Out of 4377 , subject to compulsory audit, there will remain 12 banks, 14 PAOs and several financial companies. At the same time, PAO with revenues of less than 1 million rubbles will fall under the mandatory audit criteria, but the largest companies in the alcohol industry and fuel and energy complex will fall out in Russia "[1].

The authors obviously trace the withdrawal from control of a large number of socially significant companies. We should agree with the opinion of the need to revise the criteria of social significance. The authors emphasize the rightness of a member of the board of NP "Opora Rossii", Igor Zhuravlev, reminiscent of "400 thousand defrauded co-investors who could not have been if the auditor checked the accounts of developers in time" [1]. The regulator must take into account different criteria, and not be limited only by tying to the circulation of securities on the exchange, the type of ownership, the amount of assets and revenue. The authors concluded that the reform of the state policy in relation to the compulsory audit is not logical and is not aimed at solving existing problems. At the same time, some participants of the audit market, represented by public audit associations, see in the continuation of this reform vector the threat of monopolization of the market by transnational auditors and a significant rise in the cost of services for customers in the regions [1].

\subsection{The Problems of Audit Organizations:}

The authors embarking on the consecration of the manifestation of crisis symptoms associated with the functioning of $\mathrm{AF}$ on the Russian market should note their diversity, ranging from the regulation of numbers, quality control practice and the implementation of regulatory requirements and the prestige of the profession of the auditor. As a result of the reforms and changes that have taken place, the audit market with its AF number has become like a soap bubble. According to the Ministry of Finance of Russia in 2015 year, the number of auditing organizations in which 3 or more auditors worked on a permanent basis was $36.6 \%$, organizations in which the permanent composition of auditors was less than 3 people, there were $39.6 \%$, and quite surprising facts - in $23.6 \%$ of audit firms all auditors were part-time [16, p. 21]. The presented facts testify to the deformation of the audit market. In addition, under such conditions it is difficult to count on the proper quality of the work of the audit organizations, as indicated by the annual growth of unmodified conclusions and the proportional increase in claims. This fact can be illustrated by the dynamics of revoked licenses from banks and other financial institutions (Fig.3), which received unmodified audit reports.

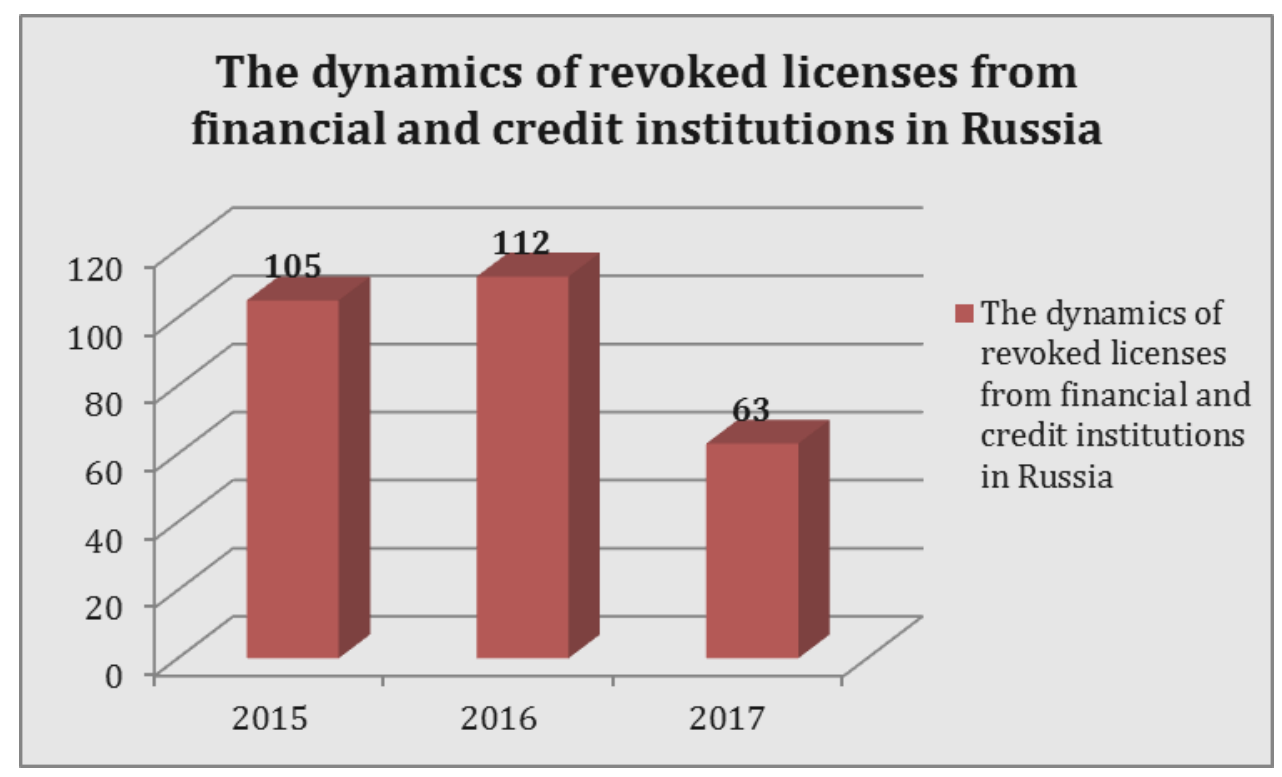

Fig.3. The dynamics of revoked licenses from financial and credit institutions in Russia Source: compiled by the authors based on [2]

The upcoming reform regulates the number of auditors for the main place of work which should be up to 
01.01.2023 year - 7 certified auditors and from 01.01.2023 year - 12 certified auditors. The proposals of the Central Bank of Russia on limiting the auditor's right to be listed in an unlimited number of audit organizations will undoubtedly exclude one of the factors contributing to unfair competition in the market. Socially-psychological self-perception of auditors at the moment is usually assessed as mentally uncomfortable. Within the framework of the research in 2016 were interviewed 42 auditors from 25 audit firms to analyse the potential risks of the industry that happened to be on the same professional seminar as the authors of this research. The fact that no reference points for the sample of recipients were initially set allows us to perceive of the data as sufficiently reliable. The biggest concern was the uncertainty in the enlarging of professional public organizations - 38\%; competition in the market - $28 \%$ and $34 \%$ were concerns and frustrations related to the position of the audit profession. Before considering these potential risks of professional activity, the authors specify the duration of AF stay on the market (See Table 1).

Table 1. The "age" of audit organizations in Russia

\begin{tabular}{|c|c|c|c|c|c|c|c|c|c|}
\hline & \multirow{2}{*}{$\begin{array}{c}\text { Number of } \\
\text { years of } \\
\text { audit work }\end{array}$} & \multicolumn{7}{|c|}{ Specific weight of audit organizations in total, \% } \\
\cline { 3 - 11 } & $\mathbf{2 0 0 9}$ & $\mathbf{2 0 1 0}$ & $\mathbf{2 0 1 1}$ & $\mathbf{2 0 1 2}$ & $\mathbf{2 0 1 3}$ & $\mathbf{2 0 1 4}$ & $\mathbf{2 0 1 5}$ & $\mathbf{2 0 1 6}$ \\
\hline $\mathbf{1}$ & $\begin{array}{c}\text { Less than } \\
\text { year }\end{array}$ & 2,8 & 9,1 & 2,0 & 3,7 & 3,5 & 4,8 & 7,2 & 6,1 \\
\hline $\mathbf{2}$ & $1-2$ years & 11,4 & 8,2 & 12,4 & 11,0 & 7,2 & 6,8 & 7,9 & 10,4 \\
\hline $\mathbf{3}$ & 3-4 years & 9,8 & 9,7 & 12,6 & 11,5 & 11,9 & 9,7 & 6,2 & 4,7 \\
\hline $\mathbf{4}$ & $\begin{array}{c}5 \text { and more } \\
\text { years }\end{array}$ & 76,0 & 73,0 & 73,0 & 73,8 & 77,4 & 78,7 & 78,7 & 79,3 \\
\hline
\end{tabular}

Source: compiled by the authors based on [6]

According to Table 1, the basis of the audit market in the last 8 years is AF working for 5 or more years and in percentage terms occupied a niche equal to more than $76 \%$. The most unsustainable market positions arose in AF at the 3rd and 4th year of auditing. At the same time, the horizontal line of the line "Less than a year" gives very important information for contemplation the features of the audit market. The "splashes" of the opening of new audit organizations were observed in 2010 and 2015 years. The first jump can be explained by an emotional upsurge in the audit community, overtaken by the prospects for self-regulation which was promised in 307-FZ. In Table 2 presents the scope of the chronology of changes in Law 307-FZ concerning audit activities.

Table 2. The chronology of increasing the requirements for the number of members of SRO auditors

\begin{tabular}{|c|c|c|c|}
\hline & $\begin{array}{c}315-\mathrm{FZ} \\
\text { "About self- } \\
\text { regulatory } \\
\text { Organizations' } \\
\mathbf{0 1 . 1 2 . 2 0 0 7}\end{array}$ & $\begin{array}{c}\text { 307-FZ "On Auditing } \\
\text { Activities' } \\
\mathbf{3 0 . 1 2 . 2 0 0 8}\end{array}$ & $\begin{array}{c}\text { 403-FZ "On the introduction } \\
\text { of changes into individual } \\
\text { legislative acts of the } \\
\text { Russian Federation " } \\
\mathbf{1 2 . 0 1 . 2 0 1 4}\end{array}$ \\
\hline Legal entities & 25 & 500 & 2000 \\
\hline Individuals & 100 & 700 & 10000 \\
\hline
\end{tabular}

Source: compiled by the authors based on [16, p.21]

The authors note that the logic and calculations, on the basis of which new quantitative requirements were legislatively established, were not previously discussed with the audit community. For two years representatives of auditing associations tried to explain to the regulator and the legislator the groundlessness of such changes. As a result, with great difficulty, by the time these standards were introduced on the 1st of January, 2017there are two professional public organizations remained on the audit market but there is a risk that can remain only one. 
The Concept of improving self-regulation mechanisms adopted in 2015 year suggests using a three-level model, where the National Self-Regulatory Union will be the highest self-regulating centre. This association should ensure uniform approaches to the control of the activity subjects of the market of audit services and the application of measures influence in cases of violations. Such decision presupposes the possibility of refraining from artificial regulation of the number of professional public associations and the inclusion of market regulatory mechanisms.

The sensations of uncertainty in the future are felt by most Russian audit organizations. With outwardly successful data on the financial potential of the audit market (Table 3), but the bulk of the proceeds go to "Big-4" companies.

Table 3. The share of "Big-4" companies in the revenue of the audit market (2014-2016), in billion rubles

\begin{tabular}{|c|c|c|c|c|c|}
\hline \multicolumn{2}{|c|}{2014} & \multicolumn{2}{c|}{2015} & \multicolumn{2}{c|}{2016} \\
\hline $\begin{array}{c}\text { The whole } \\
\text { market }\end{array}$ & "Big-4" & $\begin{array}{c}\text { The whole } \\
\text { market }\end{array}$ & "Big-4" & $\begin{array}{c}\text { The whole } \\
\text { market }\end{array}$ & "Big-4" \\
\hline 53,6 & 36,72 & 56,1 & 47,9 & 57,1 & 48,9 \\
\hline $100 \%$ & $68 \%$ & $100 \%$ & $85,4 \%$ & $100 \%$ & $85,6 \%$ \\
\hline
\end{tabular}

Source: compiled by the authors based on [6], [7]

Therefore, in the future, the regulator will have to make a decision to equalize the market distortion in terms of increasing opportunities for small and medium-sized audit firms.

A special place is occupied by the problem of the falling prestige of the profession the auditor and the related concern. Even representatives of network companies admit that they have difficulties in recruiting new personnel, predicting the discrediting of the audit institution in the next 3-4 years [10].

Considering this situation, Sheremet A.D. [11], [12], [13] identified the determinants of this problem:

- the emergence of many new prestigious well-paid economic professions that create competition for audit;

- the instability of the audit market, associated with this uncertain guarantee of earnings for employees of small / medium-sized audit firms and, a priori, the superiority of the amount of the accountant's salary, which the auditor checks, does not work for the prestige of the profession;

- the increase in the costs of preparing and passing the qualification exam, which at current market rates exceeds the average salary of an AF worker who does not have an auditor's certificate.

In the opinion of the authors, the factors affecting the decrease in the prestige of the profession the auditor in Russia are much greater, here and the constant improvement of professional skills, the work associated with seasonality and business trips, hence the irregular working day when working on the project, etc.

On the 22th of January, 2018 certified auditors in the country 19,600 people [6], that is, in 2017 year, the number was reduced by 1,135 auditors. If we take into account that the "losses" in the ratio of 20162017 years amounted to 800 people [11], then we are seeing a demographic catastrophe of the audit market.

To ensure that the profession of auditors has not disappeared from the Russian realities, the regulator must conduct constant, purposeful work. It is necessary to make this profession more acceptable for those who already work in the $\mathrm{AF}$ and those who are looking for a place to start their business career. For example, for those who already work in the AF and those who are looking for a place to start their business career, enter the correspondence preparation for the qualification exams [13, p. 4], and the exam itself is divided into modules and re-profiled in combination of knowledge / professional competencies.

Considering the list of urgent measures planned by the new auditing regulator - the Central Bank of Russia, in our opinion, priority should be given to the development of practical measures aimed at:

- the improvement of the fundamentals of the functioning of the market and the restriction of dishonesty on it; - to increasing requirements for audit organizations that provide services to socially significant organizations, and the introduction of an effective system for their accounting;

- the completion of the formation of a new model of self-regulation; 
- the development of new approaches to the qualification exam for obtaining an auditor's certificate;

- the identification of effective measures to overcome formalism in the system of professional development of auditors and external quality control.

\section{CONCLUSIONS}

The researching and analysing of the Russian audit market in the ratio of the selected ways of reform in accordance with the adopted Concept, should be encouraged by its progress and systemic nature. However, the current trends in the audit market and its environment do not allow to be inspired by the lack of reasonable confidence that the changes introduced will be sufficiently tested, and the identified institutional problems can be resolved in the short term.

\section{REFERENCE LIST}

Bulletin of SRO AAS № 11 of the June 26, 2017. (2017). http://auditorsro.org/files/pc/Vestnik/2017/06/vestnik_sro_aas_11_ot_26062017.pdf.

Internet-portal Banki.ru. (2018). The discontinued credit organizations. http://www.banki.ru/banks/memory/.

Leonid Schneidman. (2013). "Part of the auditors parasitized on mandatory audit". https://www.auditit.ru/news/audit/655596.html.

Nikiforov S.L. (2015). Are we losing it? (On prospects of the Russian audit). http://www.xn----8sb2bcau.xn-p1ai/data/documents/My-ego-teryaem.-Auditorskie-vedomosti.pdf.

Nikiforov S.L. (2017). Russian audit: cognitive dissonance (published 2-nd, supplemented). Kazan,160 pages. http://www.acg-pkf.ru/downloads/dwnl144.pdf.

Official site of the Ministry of Finance of Russia. (2018). https://www.minfin.ru/ru/perfomance/audit/monitoring/.

Official site of the rating agency "Expert". (2018). http://raexpert.ru.

Popova S.A., Semenova A.N. (2017). Analysis of the current condition of the market of audit services in Russian Federation. Economic research and development (research journal). http://edrj.ru/article/1102-17.

Roshchetayeva U.Yu. The current state of audit services in Russia. https://cyberleninka.ru/article/v/sovremennoe-sostoyanie-rynka-auditorskih-uslug-v-rossii.

Samoylov E. (2016). 3-4 years will pass and many will leave the audit. Internet resource "Anews". https://www.anews.com/p/51018270-projdet-tri-chetyre-goda-i-mnogie-ujdut-iz-audita/.

Sheremet A.D. (2017). Some problems of development of audit in Russia. Journal "Audit", №1-2017, p.4-6.

Sheremet A.D. (2015). Problems of reproduction of auditors in Russia. Audit and financial analysis, №1, p. 199-206. http://www.auditfin.com/fin/2015/1/fin 201511 rus 04 06.pdf.

Sheremet A.D. (2016). What should we do to solve the problems of auditing? "Audit”, №9, p.2-6, ISSN 22279288. http://auditor-sro.org/files/pc/news/2016/10/stat_ya_sheremeta_ad_v_zh_audit.pdf.

The approximate plan of the Concept for further development of audit activities in the Russian Federation. (2017). https://www.minfin.ru/ru/perfomance/audit/legislation/\#\#ixzz54iYczLLG.

The Ministry of Finance of Russia. The main indicators of the market of audit services in the Russian Federation. (2006-2017). https://www.minfin.ru/ru/perfomance/audit/audit_stat/MainIndex/.

Turbanov A.V. (2017). Regulation of the market of audit services. "Money and credit", №2, p.20 - 22, ISSN: 0130-3090.

Fomina D.S. (2017). Regulation and quality control in the field of auditing: reform 2018-2019. "Audit”, № 11, p. $13-19$, ISSN $2227-9288$. 